\title{
Statyba
}

\section{CHARACTER AND MECHANISM OF METALS FAILURE IN HIGH FIRE TEMPERATURES}

\section{Z. Bednarek}

To cite this article: Z. Bednarek (1996) CHARACTER AND MECHANISM OF METALS FAILURE IN HIGH FIRE TEMPERATURES, Statyba, 2:5, 6-13, DOI: 10.1080/13921525.1996.10531544

To link to this article: https://doi.org/10.1080/13921525.1996.10531544

曲 Published online: 26 Jul 2012.

Submit your article to this journal $₫$

Џ Article views: 218 


\section{CHARACTER AND MECHANISM OF METALS FAILURE IN HIGH FIRE TEMPERATURES}

\section{Z. Bednarek}

\section{Introduction}

The evaluation of the character of the failure of construction steel, resulting from the simultaneous interaction of temperature and stress, is very essential for establishing of the conditions in which the failure of the construction structures (steel structure or reinforced concrete), located within the field of increased and high temperatures, may take place. Especially significant is to explain the character of the failure of the above mentioned structures in fire conditions, i.e. under the constant load and in the temperature field, variable in time.

\section{Preliminary information}

\subsection{Character of metals failure}

The majority of metals and of technical alloys might be qualified as the semi - fragile solids with the following characteristics: subject to the external conditions - temperature, strain velocity and state of stress - they can indicate the fragile or the ductile fracture. The character of the failure is, therefore, not only depending upon the chemical composition, structure and upon the purity grade of a material.

The ductile failure is preceded by the reduction of the cross - section as a result of the considerable plastic strains, in the form of slides within the grains. In the process of formating the ductile fracture, the dominating significance has been assigned to the tangent stresses within the slide plane. It has been assumed that the development of cracks takes place as a result of appearing and coalescence of micro - cracks, and then as a result of overcoming the coherence forces within the slide planes. The development of the crack proceeds relatively slowly.

The fragile failure may proceed along the boundaries of the grains or along the characteristic separation or cleavage planes. In each of these cases the development of the fragile fracture takes place under the action of the stresses normal to the plane and surface of separation. The fragile cracking is of an avalanche character and proceeds with high velocity. Metals and alloys, mainly with a regular central A2 net, at the temperature high enough, low velocity of strain and under a defined state of stress, may indicate the characteristics of plastic materials within the process of fracture formation, however, together with the drop of temperature and with an increase of the velocity of strain or with the change of state of stress, they enter the fragile state. This phenomenon is connected with the rapid increase of the yield point, which takes place together with the drop of temperature and with the increase of the strain velocity. 


\subsection{Relation between the plastic strain and the failure process}

In case of metals the failure process is strictly connected with the plastic strain, during which the phenomenons may take place in the material, with an influence on the convertion of the fracture mechanism from a fragile into a ductile one. The failure in the material may take place as a result of the development of the original micro - cracks and also by the growth of microcracks formed during the plastic strain and connected mainly with the mechanisms of slide and twinning. A high ability to generate microcracks, influencing the development of cracking, is a characteristic feature of metals and alloys.

The quantitative effect of the plastic strain, preceding the fragile failure of the crystalline solids, is the highest in the metals with the nets of high density and decreases together with the drop of temperature and with an increase of the strain velocity. However, even in case of a fracture apparently completely fragile, it has been found out that it had been preceded by the plastic strain. It has been proved by the appearance of the superfacially strengthened layers on the fragile fractures, by means of cold work and deformation twins. However, the plastic strain, preceding the cracking of metal, cannot be reduced only to the effects having been monitored on the fractures (1).

An essential importance should be assigned to the mechanisms of damping the plastic flow and of germing of the microcracks. It is possible to assume that damping the yield point $\mathrm{Re}$, at the high velocities of strain, creates the conditions to develop the cracks, causing the fragile failure. Despite of the fact, that the importance of the plastic strain for the appearance of the fragile cracking of metals remains beyond any discussion, the differences of standpoints exist concerning the range of the mutual interaction of these phenomenons. According to the presently accepted standpoints, the process of transcrystaline (ductile) failure takes place within three stages (2):

- formation of dislocations,

- germing of microcracks,

- development of microcracks.

Under certain circumstances, these phenomenons proceed subsequently in the continuous way, and the development of each of them prepares the conditions to start a next one, which is characteristic in case of a failure of ductile character. The growth of microcracks is supposed to constitute the critical stage of failure. It means that if prior to the appearance of the first microcracks the preconditions necessary to develop the fracture have been fulfilled, their avalanche growth takes place simultaneously with the appearance of the microcracks. This corresponds with the fragile failure (3). On the other hand, at the stress equal to the yield point, the microcracks may appear in the material, however, if there are no conditions for their growth, the fragile failure will not take place. However, the closing of microcracks appears.

\subsection{Germing of microcracks in technical alloys}

The phases are incorporated in the technical alloys, which have the form of dispersion separation or of the nonmetalic entities, differing significantly from the matrix. The so called " hard " separations are considered, where the transfer of dislocations is not taking place, and the so called " soft " separations, which do not constitute any barrier for the transfer of dislocations. In metals and technical alloys there are the following germs of cracking: the different faults and incontinuities resulting from the technological process as well as voids and micropores within the interphase boundaries, caused by nonadjustment of the crystalline net (4).

During the straining of an alloy, comprising the hard separations, the bands of slides are generated in their vicinity, the blockade of which causes the germing of the cracks on the interphase boundary. 
Under certain circumstances, especially in case of variable loads, the hard separations may be subjected to cracking in the process of plastic strain. If the separations are big enough, the arising cracking reaches the critical magnitude, fulfilling certain conditions, what results in the growth of fragility of the material.

The alloys comprising the soft separations indicate usually a higher value of the yield point than the matrix free of the separations. However, they indicate the sane cohesion strength, what means the higher ability to the fragile failure.

The present state of the theoretical knowledge and the level of development of the research methods do not enable a final conclusion which of the mechanisms of germing of microcracks should be recognized as dominating during the cracking of the material.

\subsection{Failure of material in the conditions of creep}

The conditions of the creep test differ substantially from the conditions of the ordinary tension test in increased temperatures; the constant stress and the constant temperature have been applied and what is of a special importance - these are the long-term tests, with a relatively low strain velocity.

It has been found out that the ductile failure has been proceded by the reduction of the cross section of the sample as a result of high creep strains, resulting from the slides within the grains. The failure takes place by the way of propagation of cracks along the slide planes. It has been stated, that the ductile failure takes place in low temperatures, at the high levels of stresses and at high strains.

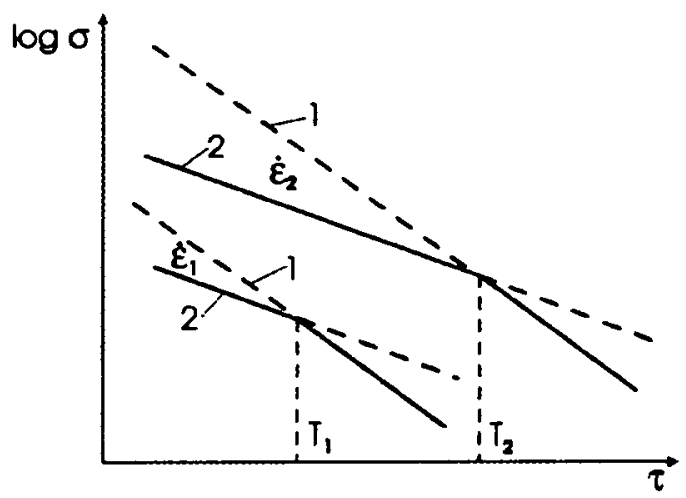

Fig. 1. Tests results of steel failure with creep influence of temperature and of strain velocity on the character of failure: 1 - cracking on the boundaries of grains 2 - slide within grains

The fragile failure is a result of weakening of the material due to the appearance of microcracks on the boundaries of the grains, what reduces the effective surface of the cross - section of the sample. After the critical value has been exceeded by this cross - section, the failure of the sample takes place. The fragile failure takes place at the low levels of stresses, in high temperatures and at low strains. The influence of the temperature and of the creep velocity on the type of failure has been presented on Figure 1. This is to emphasize, that even in case of the short-term creep tests the testing period is at least $10^{3}$ hours. According to the diagram, up to the limit temperature $T_{1}$ (strain velocity $\varepsilon_{1}$ ) or $\mathrm{T}_{2}$ (strain velocity $\varepsilon_{2}$ ), the failure takes place as a result of the dominating interaction of the reason No. 2 /i. e. of the slides within the grains, and is of a ductile character. After the critical temperature has been exceeded, the cracks on the boundaries of the grains have a dominating influence on the character of the failure and they cause the fragile failure. On Figure 2 it has been shown, how the character of the failure changes during the creep together with an increase of temperature. In the temperature of $933 \mathrm{~K}\left(660^{\circ} \mathrm{C}\right)$, constituting 0.5 of the melting point temperature for iron, the failure is of a fragile character, and in the temperature of $773 \mathrm{~K}\left(500^{\circ} \mathrm{C}\right)$ - the failure is of a ductile 
character. Evidently, the temperature in which the character of the failure changes, is related to the strain velocity.

The third period of creep, preceding the failure, indicates the increasing creep velocity. The transition to this period cannot be explained by a single reason. This is a complex process. The increase of velocity in the third period of creep is probably connected with the increase of stress, caused either by the formation of neck or of voids, or of both these phenomenons simultaneously. Practically, during the creep tests in the third period we face increase of stresses at the constant loads.

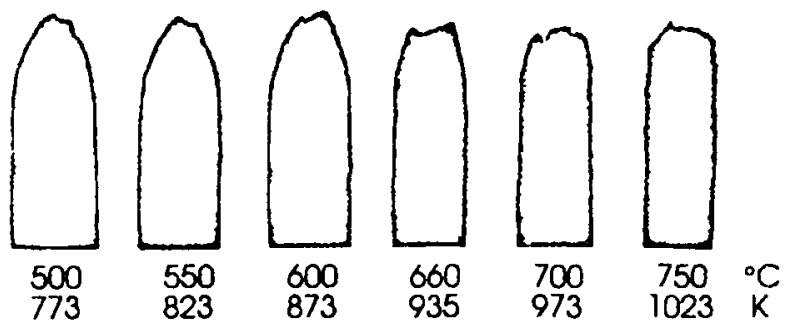

Fig. 2. Character of failure of the stainless steel samples $(10 \% \mathrm{Cr}, 95 \% \mathrm{Ni})$ in raised and high temperatures

At the high stresses the microcracks have not been found on the boundaries of grains, therefore, the third period of creep was combined only with the formation of the neck. However, during the tests it has been noticed that the formation of the neck is not adjusted to the begining of the third period of creep. The begining of the third period of creep may appear at the strains at which the neck has not yet been formed.

During the creep tests at the medium stresses, the third period of creep has been caused by the formation of the round voids directly under the surface of the sample; the formation of the neck starts immediately, and then the number of voids increases along the axis of the sample within the zone of the neck.

During the creep tests at the low stresses, the neck has not been formed at all or has been very unsignificant. In this case, the third period of creep has been combined with an appearance and growth of microcracks on the boundaries of grains, which were visible in the full volume of the working length of the sample.

\section{Character of steel failure in the conditions of the undefimed temperature field (the own tests of the author)}

The tests have been carried out in the thermal conditions defined by the " temperature - time " function, which corresponds with the tem-perature distribution, obtained by theoretical means, existing in the main reinforcement of the bended reinforced concrete items (5).

The samples were subjected to the constant loads (the constant "technical " stresses).

Figure 3 presents the diagram of the test course, and the figures No. 4, No. 5 and No. 6 present the samples of construction steel Grade St 3, Grade $18 \mathrm{G} 2$ and Grade $34 \mathrm{GS}$, located in the sequence corresponding with the decrease of the level of stresses $\sigma / R_{e}$ from 1 to 0.2 approximately. In all the grades of steel the visible changes of fracture take place in the direction of the increase of fragibility together with the increase of the level of stresses. As it is evident in case of Grade St 3 steel, the transition from the fragile fracture to the fragile/ductile fracture takes place at the higher levels of stresses than in Grade 18 G2 steel and in Grade 34 GS steel. In case of Grade 34 GS steel, the transition towards fragility appears at the much lower levels of stresses. In case of Grade $34 \mathrm{GS}$ steel, at the level $\sigma / R_{e}=0.84$, the fracture is completely fragile. 

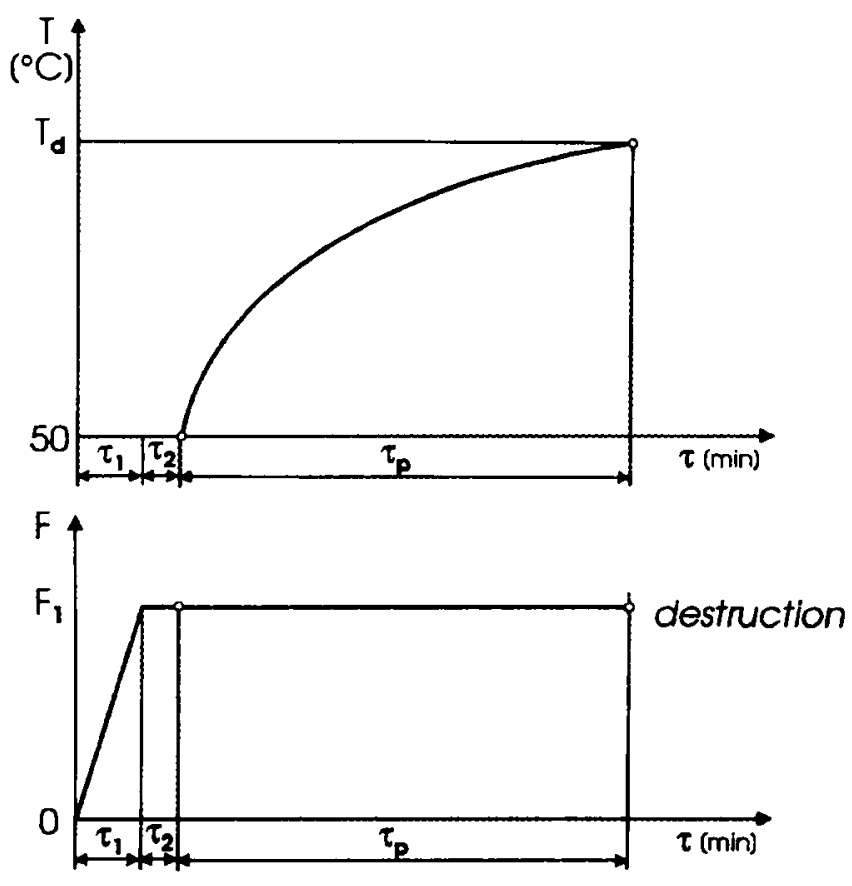

Fig. 3. Diagram of test course

It should be also taken into consideration, that although the temperature in all the tests, which gave the results in the form of fractures presented on the figures No. 4, No. 5 and No. 6, was increasing according to the same curve, the final temperature was always higher in case of the lower level of stresses. However, these differences are not very significant.
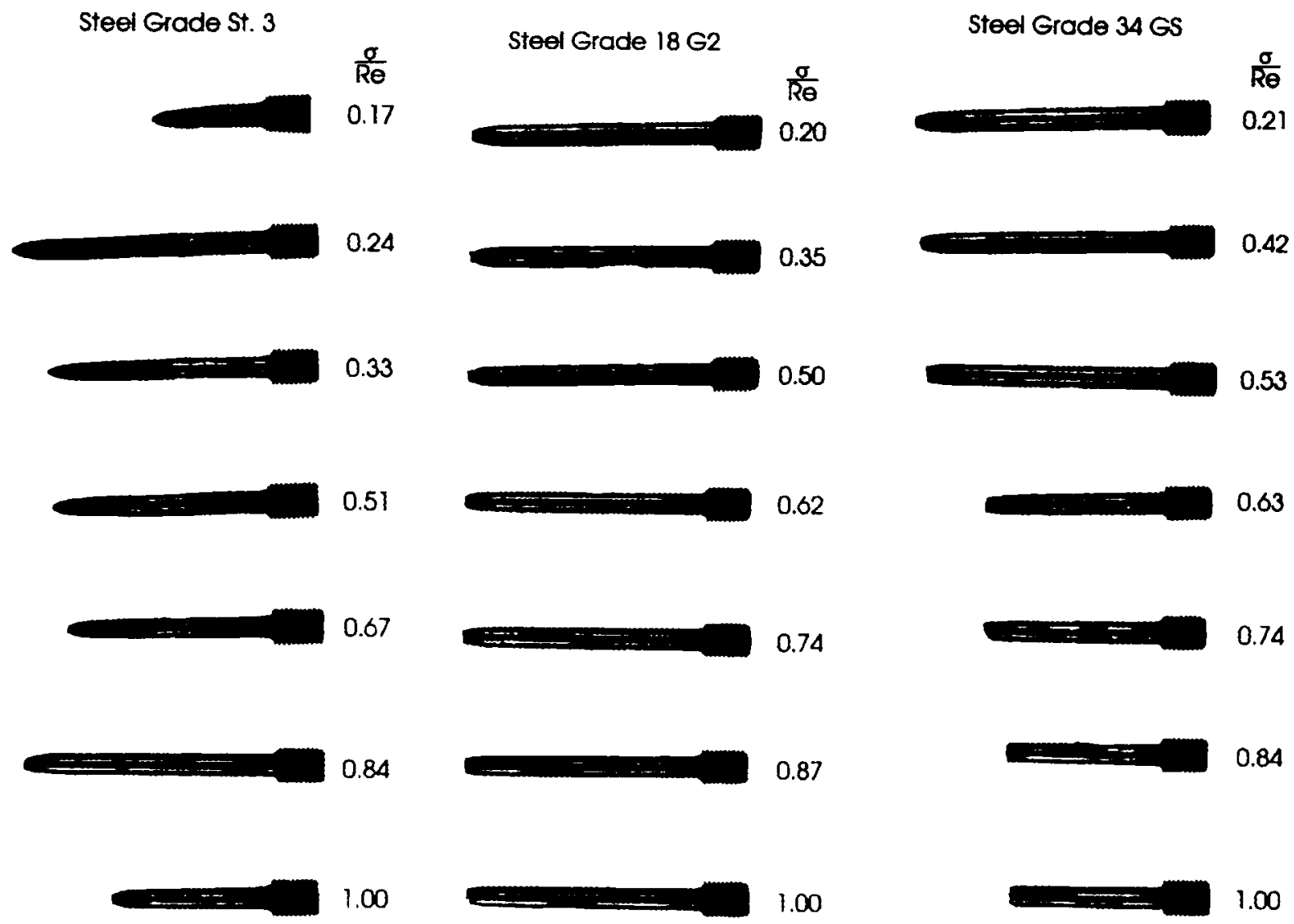

Fig. 4. Grade St 3 steel samples after Fig. 5. Grade 18 G2 steel samples rupture after rupture.

Fig. 6. Grade 34 GS steel samples after rupture 
Figure 7 presents the fractures of the samples obtained for the two levels of stresses $(0.5$ and 0.87 ) at the different distribution of temperatures, indicated as " $\mathrm{X}=15$ " (the most severe), " $\mathrm{X}=35$ " and " $\mathrm{X}=75$ " (the most modest). From the figure one may conclude that the relatively low differences between the final temperatures do not significantly influence the change of the character of the fracture, however, the level of stresses plays a considerable role.

Steel Grade $18 \mathrm{G} 2$

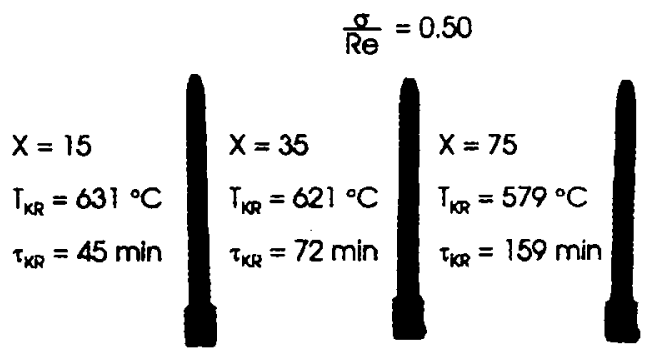

$$
\begin{aligned}
& X=15 \\
& T_{K R}=577^{\circ} \mathrm{C} \\
& \tau_{K R}=36 \mathrm{~min}
\end{aligned}
$$

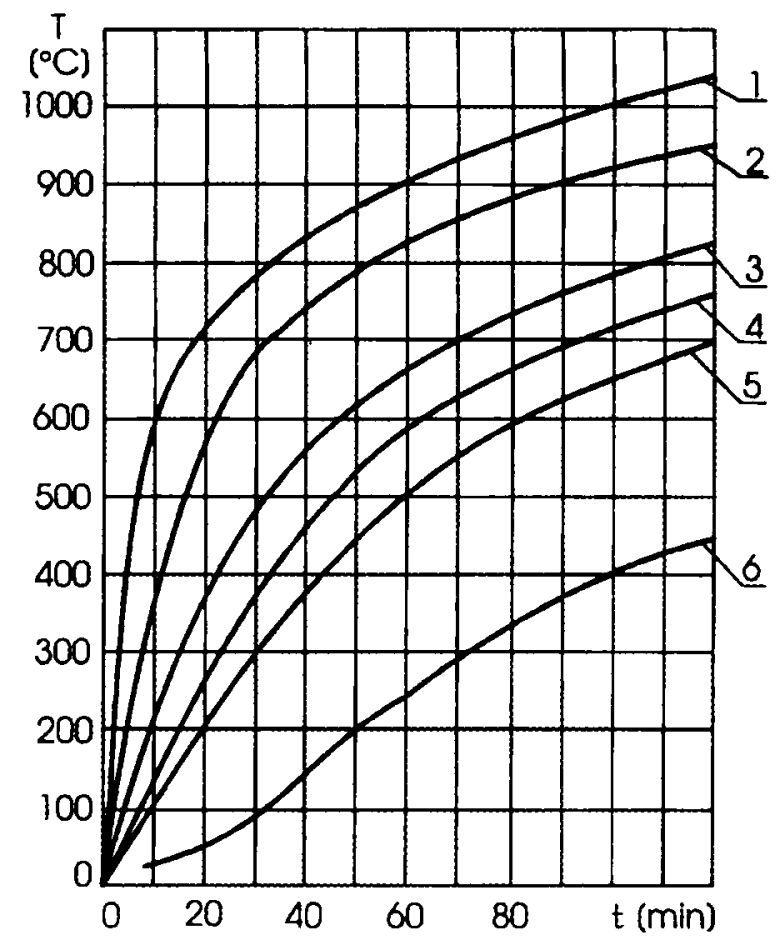

Fig. 8. "Temperature - time " distribution assumed in the tests
Fig. 7. Samples after rupture from the tests carried out in the various thermal conditions (" temperature - time " distribution $X=15, X=35, X=75$ according to Fig. 8)
In all the presented cases, heating was taking place after the samples have been loaded up to the established level of stresses. The stresses oscillated in the direction of the yield point. According to the analysis, the period of sudden appearance of the high number of free dislocations seems a good moment for formation of a micro-crack and for its growth; the above takes place at the stresses equal to the yield point. The phenomenon of fragility in case of steel is connected with the yield point and is dependant upon the factors which are blocking dislocation; for example: admixtures of the inter-boundary atoms - carbon, nitrogen. In case of dropping of the level of stresses, the stresses started to differ from the yield point and, therefore, the conditions supporting the formation of microcracks, before the starting up of heating, disappeared. 
The metalographic tests, carried out after the failure of the samples, indicate the presence of the cold work in the material, increasing together with an increase of the level of stresses $\sigma / \mathbb{R}_{e}$. The metalographic tests, concerning the low - alloy Grade $18 \mathrm{G} 2$ steel, indicated that the cold work ratio is to high extend dependant upon the level of stresses, existing during the tests: $\sigma / R_{c}(\sigma-$ the constant stresses assumed for the tests, $R_{c}$ - the yield point in normal temperature). The tests carried out at the uniform "temperature-time" distribution (No. 4) indicated the cold work amounting to: $70 \%$ for $\sigma / R_{e}=$ $0.2,35 \%$ ( Fig. 9) approximately for $\sigma / \mathbb{R}_{e}=1$. In the last case a fragile fracture has been recorded.

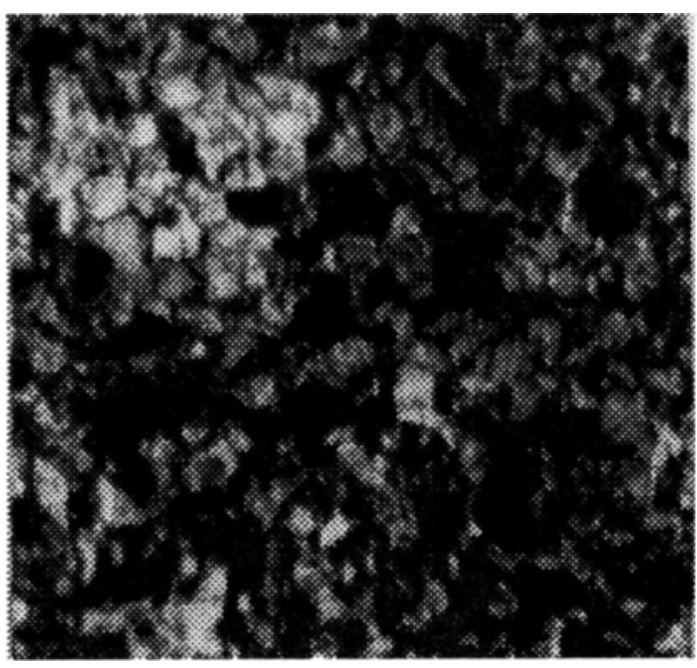

a)

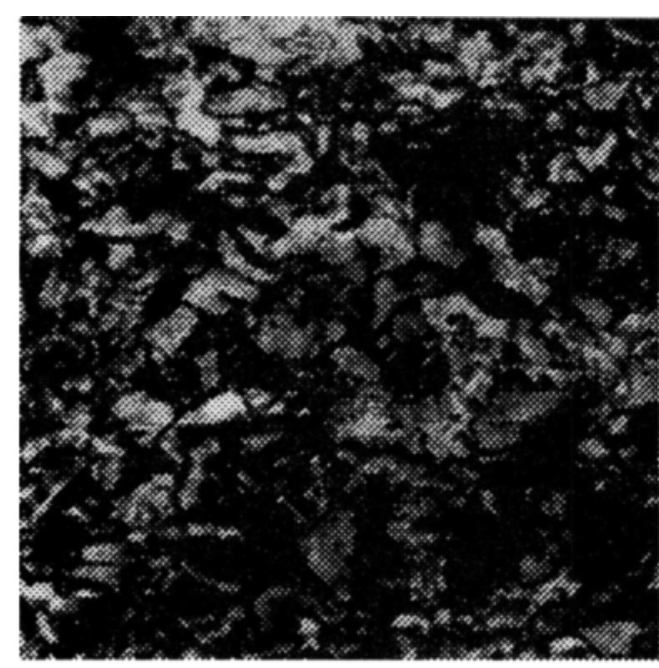

b)

Fig. 9. Fractures of samples a) $\sigma / R_{c}=0.2$ b) $\sigma / R_{c}=1$

Also in case of the uniform levels of stresses, however at different temperature distributions, the differences in the cold work ratio exist, what has been indicated by the test results included in Table No. 1 .

Table 1.

\begin{tabular}{|c|c|c|}
\hline Temperature distribution & Level of stresses $\sigma / \mathbb{R}_{\boldsymbol{c}}$ & Cold work ratio [\%] \\
\hline \multirow{2}{*}{ No. 3 } & 0.50 & 80 \\
\cline { 2 - 3 } & 0.87 & 70 \\
\hline \multirow{2}{*}{ No.5 } & 0.50 & 50 \\
\cline { 2 - 3 } & 0.87 & 40 \\
\hline \multirow{2}{*}{ No. 6 } & 0.50 & 50 \\
\cline { 2 - 3 } & 0.87 & 40 \\
\hline
\end{tabular}

This is to emphasize that the "temperature - time " curve and the level of stresses affect the strain velocity of samples ( $\varepsilon$ ).

One may assumethat a relation between " ductility " and " fragility " of the fracture is dependant upon the stress existing the sample prior to the increase of the temperature (what has been discussed), upon the increase of the temperature and upon the strain velocity. The increase of the strain temperature causes the rapid decrease of the yield point; on the other hand, the increase of the strain velocity transfers the yield point in the direction of higher values of stresses and even leads to its damping. 


\section{Conclusions}

Analysing all the factors and preconditions of fracture formation, of the character of failure and of combined mechanisms, the following conclusions may be drawn:

1. In the process of failure of construction steel (Grade St3 S, Grade 18 G2, Grade 34 GS), most frequently the mixed fragile / ductile failure appears with the dominating influence of one of these kinds of failure.

2. In all the types of tests (a standard tension test, a creep test, a tests at a constant load and in the temperature field, variable in time) the conditions exist which cause the germing of the microcracks and their growth preceding the failure of the material.

3. It is impossible to separate and to finally define an influence of the specific factors (stresses, temperature and strain velocity) on the character of the failure of material. It is always subjected to the adequate combination of the above mentioned factors.

4. The plastic strain of steel is indespensable to initiate the fragile failure. Even in case of an apparently completely fragile fracture, it has been found out that it has been preceded by the plastic strain. It has been confirmed by the appearance on the fragile fractures of the superfacially strengthened layers, by means of the cold work, what has been also noticed during the own tests of the author.

5. An essential significance at the formation of the fragile failure shall be assigned to the mechanisms of damping the plastic flow. The damping of the yield point $R_{e}$, at the high strain velocities, creates conditions to develop the cracks resulting in the fragile failure.

Under the conditions of rapidly increasing temperatures, what takes plane during a fire, the fragile failure of the steel structures or of the reinforcement of the reinforced concrete structures may take place, especially dangerous due to the lack of any visible strains preceding the failure.

\section{References}

1. A. Maciejny. Kruchoś metali. Śląsk, 1973.

2. G.T. Halm an others. Conference on fracture. Massachusetts, 1959, John Wiley, New York, 1959.

3. J. Gouzon. Problems fundamentaux de la deformation et de la rupture de l'acier. Liege. CNRM, 1966.

4. В.М. Финкель. Физика разрушения. М., 1970.

5. Z. Bednarek Określenie parametrów wytrzymałosciowych materiałów konstrukcyjnych $w$ nieustalonym polu temperatur. Materiały konferencji „Badania pożarow”. Warszawa, 1989.

\section{Iteikta 19960420}

\section{METALŲ SUIRIMO AUKŠTOJE TEMPERATŪROJE POBŪDIS IR MECHANIZMAS}

\section{Z.Bednarek}

\section{S a n t r a u k a}

Analizuojama plieno veikiama pastovios apkrovos ir kintamo temperatūros lauko elgsena. Pateikiama preliminari informacija, charakterizuojanti veiksnius, kurie lemia plieno suirimo pobūdị (trapų ar plastišką). Pagrindinis dèmesys skiriamas temperatūros, deformaciju greičio, ịtempimų būviams apibūdinti. Nurodoma, kad irimas prasideda vystantis natūraliems bei augant plastinių deformaciju sukeltiems mikroplyšiams.

Nustatyta, kad tirtų konstrukciniu plienu trapiai plastiškas irimas vyksta dominuojant vienai iš irimo rūšių. Tyrimai, atlikti ịvairiomis sąlygomis, parodé, kad suirimą sukelia mikroplyšiu atsiradimas ir plétimasis. Suirimo pobūdị (trapy ar plastišką) lemia įtempimų lygis, temperatūros ir deformacijų greičiai, be to, veiksniai yra tarpusavyje susiję. Plastinès deformacijos inicijuoja net ir visiškai trapų suirimą. Ypač svarbus suirimo formavimuisi plastinio tekèjimo gesinimas, esant dideliems deformacijų greičiams.

Atlikti tyrimai liudija, kad plieno elementai ar gelžbetoninių elementų armatūra gaisro metu gali trapiai suirti. 